\title{
THE EFFECTS OF THERMAL ANNEALING ON FRACTURE TOUGHNESS OF LOW UPPER-SHELF WELDS*
}

\author{
Mikhail A. Sokolov, Randy K. Nanstad, and Shafik K. Iskander \\ Metals and Ceramics Division \\ OAK RWGE NATIONAL LABORATORY \\ P.O. Box 2008 \\ Oak Ridge, TN 37831-6151
}

\begin{abstract}
${ }^{*}$ Research sponsored by the Office of Nuclear Regulatory Research, U.S. Nuclear Regulatory Commission, under Interagency Agreement DOE 1886-8109-8L with the U.S. Department of Energy under contract DE-AC05-840R21400 with Lockheed Martin Energy Systems.
\end{abstract}

\section{DISTRIBUTION OF THIS DOCUIAENT IS LNLIMITED aT \\ The submitted manuscript has been authored by a contractor of the U.S. Government under contract No. DE-ACO5-84OR21400. Accordingly, the U.S. Government relains a nonexclusive, royalty-free license to publish or reproduce the published form of this contribution, or allow others to do so, for U.S. Government purposes.}

\section{DISCLAIMIER}

\begin{abstract}
This report was prepared as an account of work sponsored by an agency of the United States Government. Neither the United States Government nor any agency thereof, nor any of their bility for the accuny warranty, express or implied, or assumes any legal liability or responsiprocess disclosed, or represents that its usefulness of any information, apparatus, product, or ence herein to any specific commercial use would not infringe privately owned rights. Refermanufacturer, or otherwise does not necessarily const, or service by trade name, trademark, mendation, or favoring by the not necessarily constitute or imply its endorsement, recomand opinions of authors expressed States Government or any agency thereof. The views United States Government or any agency thereof. necessarily state or reflect those of the
\end{abstract}


Mikhail A. Sokolov, ${ }^{1}$ Randy K. Nanstad, ${ }^{1}$ and Shafik K. Iskander ${ }^{1}$

\section{THE EFFECTS OF THERMAL ANNEALING ON FRACTURE TOUGHNESS OF LOW UPPER-SHELF WELDS}

REFERENCE: Sokolov, M. A., Nanstad, R. K., and Iskander, S. K., "The Effects of Thermal Annealing on Fracture Toughness of Low Upper-Shelf Welds," Effects of Radiation on Materials: 17th Volume, ASTM STP 1270, David S. Gelles, Randy K. Nanstad, Arvind S. Kumar, and Edward A. Little, Editors, American Society for Testing and Materials, Philadelphia, 1996.

ABSTRACT: Experimental results are presented from a study of the effects of thermal annealing on recovery of fracture toughness of low upper-shelf submerged-arc welds (weld designations 61W through 67W) from the Heavy-Section Steel Irradiation (HSSI) Program Second and Third Irradiation Series. Most of the study was conducted to evaluate the effects of annealing on the J-R curves of the submerged-arc welds. The recovery of fracture toughness in the transition range as the result of annealing was studied for welds $63 \mathrm{~W}, 64$, and $65 \mathrm{~W}$ only. Compact specimens of 12.7 - and 20.3-mm-thick ( $0.5 \mathrm{~T}$ and $0.8 \mathrm{~T}$, respectively) were tested in this study. The specimens had been previously irradiated at the Oak Ridge National Laboratory (ORNL) Bulk Shielding Reactor. Each weld was irradiated to a certain value of neutron fluence in the range from 0.4 to $1.3 \times 10^{19}$ neutrons $/ \mathrm{cm}^{2}(>1 \mathrm{MeV})$ in the average temperature range of 275 to $300^{\circ} \mathrm{C}$. Annealing of the irradiated specimens was done at $454^{\circ} \mathrm{C}$ for $168 \mathrm{~h}$. Fracture toughness tests were performed at temperatures selected to match those of the previously conducted unirradiated and irradiated tests.

KEYWORDS: fracture toughness, annealing, low upper-shelf weld

\section{INTRODUCTION}

Prevention of reactor pressure vessel (RPV) failure in light-water moderated nuclear power reactors depends primarily on maintaining the RPV material fracture toughness at levels that will resist fracture, either brittle or ductile, during plant operation, including normal and emergency conditions. A number of reactor vessels in commercial

'Metals and Ceramics Division, Oak Ridge National Laboratory, Oak Ridge, TN 37831-6151. 
pressurized-water reactor (PWR) plants include welds with both relatively low initial Charpy V-notch (CVN) upper-shelf energies and high copper concentrations that make them highly sensitive to neutron irradiation. Accordingly, the fracture toughness requirements of Title 10, Code of Federal Regulations, Part 50 (10CFR50), Appendix G [1], may not be met by some beltline weld materials as the RPV approaches the end of design life. The regulations require, as an option, that a fracture mechanics analysis be performed that conservatively demonstrates adequate safety margins for continued operation. Otherwise, thermal annealing may need to be performed to recover the fracture toughness of the embrittled materials.

The object of this present study is the effect of thermal annealing on recovery of fracture toughness of low upper-shelf submerged-arc welds (weld designations 61W through 67W) from the HSSI Program Second and Third Irradiation Series and the behavior of annealed welds upon reirradiation. This paper describes the first stage of this study, which is associated with creation of a database of fracture toughness recovery of high-copper, low upper-shelf submerged-arc welds after thermal annealing. In the second stage, this database will be used to study the degradation of fracture toughness properties upon reirradiation.

The HSSI Program Second and Third Irradiation Series were conducted in the late 1970 s and early 1980s to examine irradiation effects on the tearing resistance of these welds by means of J-R curve testing. The J-R curve characterization of the welds studied [2,3] concluded that (1) irradiation significantly decreased the critical values of J-integral near onset of slow stable crack growth $\left(\mathrm{J}_{\mathrm{Ic}}\right)$ and the tearing modulus $\left(\mathrm{T}_{\text {avg }}\right)$ from the preirradiation values, and (2) $\mathrm{T}_{\text {avg }}$ was a more discriminating indicator of the degradation in fracture toughness than $\mathrm{J}_{\mathrm{Ic}}$. Fracture toughness tests were not conducted at temperatures where cleavage would occur. More detailed presentations are given in Refs. [2,4,5], while Ref. [6] provides a summary of all of the irradiation series conducted under the HSSI Program.

\section{MATERIALS AND IRRADIATION HISTORY}

As previously described [2,4], the seven submerged-arc welds, identified as HSSI welds $61 \mathrm{~W}$ through $67 \mathrm{~W}$, were fabricated with materials and procedures used in early PWRs. These welds had average copper levels ranging from 0.21 to $0.42 \%$ with nickel levels of around $0.6 \%$ and, thus, were considered "sensitive" to neutron irradiation embrittlement and typical of some early pressure vessel welds. The use of Linde 80 flux produced welds with large contents of very small inclusions, leading to relatively low CVN upper-shelf energies. Chemical compositions and postweld stress-relief heat treatments of the welds are presented in Table 1. 
TABLE 1--Chemical compositions and postweld stress-relief heat treatments of HSSI welds $61 \mathrm{~W}$ through $67 \mathrm{~W}$

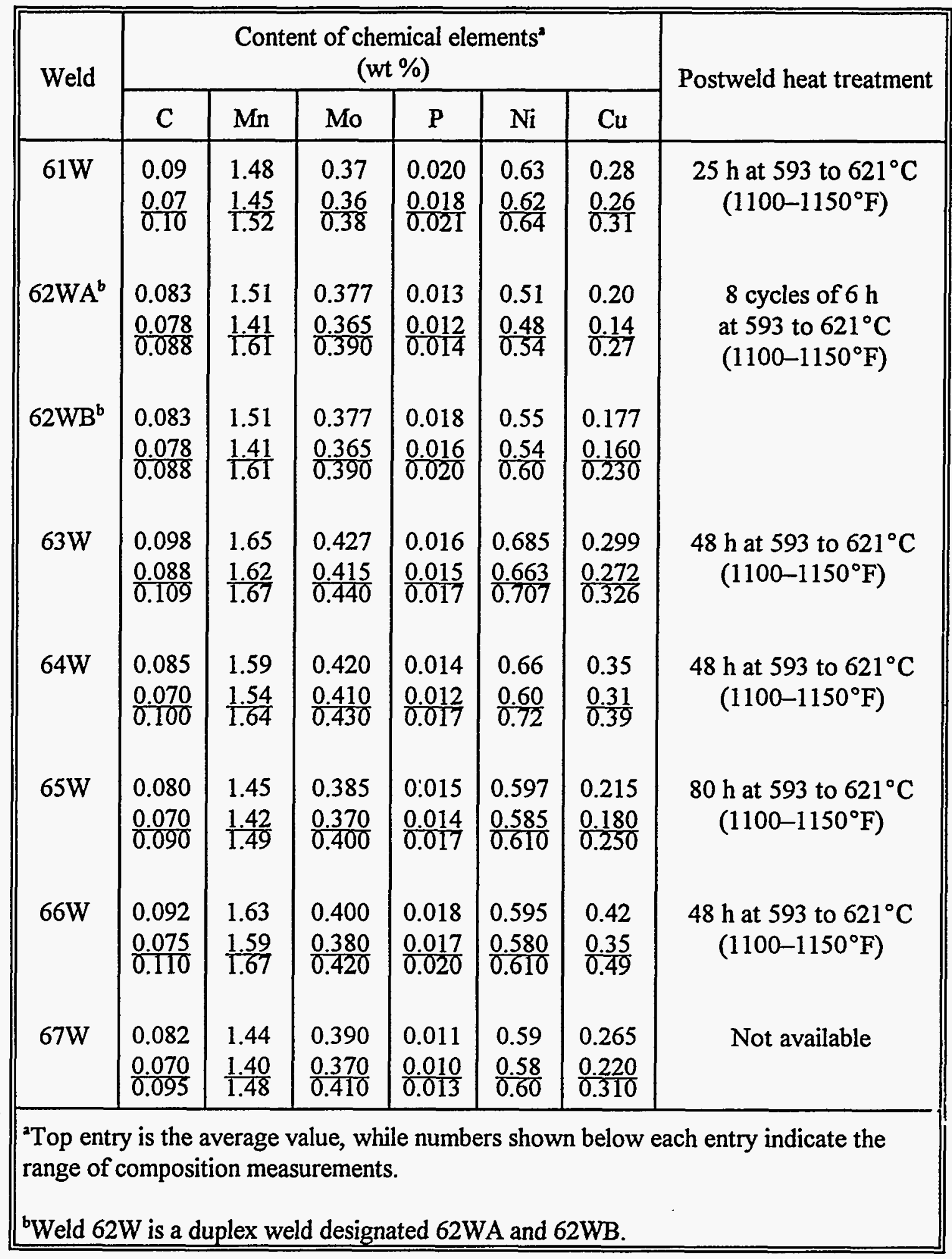


The design of the irradiation capsules was based on the irradiation of two 101.6-mm-thick compact specimens [4TC (T)] in one capsule. In addition to the 4TC (T) fracture toughness specimens, $0.5 \mathrm{~T}, 0.8 \mathrm{~T}$, and $1.6 \mathrm{TC}(\mathrm{T})(12.7,20.3$, and $40.6 \mathrm{~mm}$ thick, respectively), $\mathrm{CVN}$, and tensile specimens were included in the irradiation capsules. The first capsule was loaded for irradiation into the Bulk Shielding Reactor in November 1976, while the last capsule was removed from the reactor in March 1978 [6]. A total of six capsules were irradiated under the Second and Third Irradiation Series.

Because of neutron flux gradients through the 101.6-mm (4-in.) thickness of the largest specimens, the capsule design provided for $180^{\circ}$ rotation of the capsules during the irradiations. These rotations were scheduled to average total neutron fluence through the thickness of the 4TC (T) specimens. The neutron flux for the specimens varied, depending on location in the capsule, but averaged about $1 \times 10^{12}$ neutrons $/\left(\mathrm{cm}^{2} \cdot \mathrm{s}\right)$ $(>1 \mathrm{MeV})$ [7]. Each weld was irradiated to a certain value of neutron fluence in the range from 0.4 to $1.3 \times 10^{19}$ neutrons $/ \mathrm{cm}^{2}(>1 \mathrm{MeV})$.

The primary temperature control was at the fatigue crack front of the 4TC (T) specimens with a target irradiation temperature of $288^{\circ} \mathrm{C}\left(550^{\circ} \mathrm{F}\right)$. Since there was no independent control of temperatures for the small specimens, they were irradiated over a temperature range about $288^{\circ} \mathrm{C}$, depending on their location in the capsules and the degree of thermal contact between them and the 4TC (T) specimens. These temperatures were also different in the forward and reverse position. Thus, the irradiation temperature for each specimen is an average of the temperatures experienced in the forward and reverse positions. Additional details of capsule design and operation conditions are contained in Ref. [4].

The specimens for the present annealing/reirradiation study were chosen to be as comparable as possible with the irradiation conditions (temperature and neutron fluence) of specimens tested in the previous irradiation study [2]. Moreover, due to uncertainties in copper content, as well as variations in irradiation conditions and toughness properties after irradiation $[2,4]$, weld $62 \mathrm{~W}$ was not included in this study.

\section{TEST MATRIX}

Annealing of all specimens was performed at $454^{\circ} \mathrm{C}$ for $168 \mathrm{~h}$. The annealing furnace in the hot cell was set to heat specimens at the rate of $20^{\circ} \mathrm{C} / \mathrm{h}$ up to $454^{\circ} \mathrm{C}$, then keep the specimens at this temperature for $168 \mathrm{~h}$. After annealing for $168 \mathrm{~h}$, the furnace was turned off automatically and specimens were cooled in the furnace.

Two $0.5 \mathrm{~T}$ compact specimens of each weld were assigned for the tearing resistance characterization in each annealed and reirradiated conditions. Additionally, all available $0.8 \mathrm{TC}(\mathrm{T})$ specimens were tested after annealing. J-R curve tests in the ductile range were performed at temperatures selected to match those of the unirradiated and irradiated tests [2]. 
Six $0.5 \mathrm{TC}(\mathrm{T})$ specimens of welds $63 \mathrm{~W}, 64 \mathrm{~W}$, and $65 \mathrm{~W}$ were selected for fracture toughness tests in the transition range after thermal annealing and reirradiation. Transition fracture.toughness of these three welds in the unirradiated condition has been determined by testing of 12 precracked CVN (PCVN) specimens of each weld. For weld 63W, only three Charpy specimens were available initially. The rest of the specimens for that weld were obtained by weld reconstitution of broken 63W Charpy halves at the Kurchatov Institute, Moscow, using inserts no shorter than $17 \mathrm{~mm}$ that consisted of $63 \mathrm{~W}$ weld metal only. After reconstitution, the specimens were notched and fatigue precracked.

All specimens were tested with a single-specimen unloading compliance procedure. PCVN specimens were tested in three-point slow bending while measuring load versus load-line displacement. Unfortunately, the design of the already irradiated compact specimens did not allow for placement of the clip gage on the load line. To overcome this problem, razor blades were spot-welded to the front face of the specimens (crack mouth) and the clip gage was attached to the razor blades. The front face displacements were converted to load line displacements using a geometric correction factor that accounted for the specimen center of rotation [8].

Table 2 provides the irradiation conditions, test temperatures, and the fracture toughness properties (discussed in the next section) after annealing at $454^{\circ} \mathrm{C}$ for $168 \mathrm{~h}$.

\section{RESULTS AND DISCUSSION}

\section{Fracture Toughness in the Transition Region}

With testing of the PCVN and 0.5T compact specimens of 10 and $12.7 \mathrm{~mm}$ thickness, respectively, some amount of local crack tip plasticity was present and fracture toughness up to cleavage instability was calculated in terms of the J-integral, $\mathrm{J}_{\mathrm{c}}$. Then the $\mathrm{J}_{\mathrm{c}}$ is converted to its equivalent in terms of the elastic-plastic stress intensity factor, $\mathrm{K}_{\mathrm{Jc}}$. The $\mathrm{K}_{\mathrm{Jc}}$ values are size-dependent and distinguished by a broad scattering in the transition region. To characterize the elastic-plastic fracture toughness of welds studied, the $K_{s c}$ data were analyzed by a procedure based on the earlier work by Wallin [9] and developed in an American Society for Testing and Materials (ASTM) draft standard on test method for fracture toughness in the transition range. ${ }^{1}$ The procedure uses weakest-link theory to adjust for specimen size effects so that data equivalent to that for a $1 \mathrm{~T}$ specimen size $\left[\mathrm{K}_{\mathrm{Jc}(1 \mathrm{~T})}\right]$ can be calculated from data measured with specimens of different sizes $\left[\mathrm{K}_{\mathrm{Jc}(\mathrm{X})]}\right]$ as follows:

1"Determination of Reference Temperature, $T_{0}$, for Ferritic Steels in the Transition Range," Draft 11, Task Group E08.08.03 on Ductile-Brittle Transition, American Society for Testing and Materials, Philadelphia, 1995. 
TABLE 2--Irradiation conditions and test data of the specimens studied

\begin{tabular}{|c|c|c|c|c|c|c|c|}
\hline Specimen & $\begin{array}{l}\text { Specimen } \\
\text { Type }\end{array}$ & $\begin{array}{l}\mathrm{T}_{\mathrm{ir}}^{\mathrm{b}} \\
\left({ }^{\circ} \mathrm{C}\right)\end{array}$ & $\begin{array}{c}\text { Neutron } \\
\text { fluence } \\
\left(10^{18} \mathrm{n} / \mathrm{cm}^{2}\right)\end{array}$ & $\begin{array}{l}\mathrm{T}_{\text {tert }} \\
\left({ }^{\circ} \mathrm{C}\right)\end{array}$ & $\begin{array}{c}\mathrm{J}_{\mathrm{le}}{ }^{\mathrm{d}} \\
\left(\mathrm{kJ} / \mathrm{m}^{2}\right)\end{array}$ & $T_{\text {avg }}$ & $\begin{array}{c}\mathrm{K}_{\mathrm{k}}{ }^{\mathrm{r}} \\
(\mathrm{MPa} \sqrt{\mathrm{m}})\end{array}$ \\
\hline $\begin{array}{l}61 W-043 \\
61 W-101 \\
61 W-130\end{array}$ & $\begin{array}{l}0.8 \mathrm{~T}(10) \\
0.5 \mathrm{~T}(20) \\
0.5 \mathrm{~T}(20)\end{array}$ & $\begin{array}{l}303(278 / 328) \\
281(274 / 288) \\
309(285 / 334)\end{array}$ & $\begin{array}{c}12.0(3.2 / 8.8) \\
15.9(3.2 / 12.7) \\
13.3(2.2 / 11.1)\end{array}$ & $\begin{array}{l}121 \\
121 \\
121 \\
\end{array}$ & $\begin{array}{l}187(181) \\
111(105) \\
129(126)\end{array}$ & $\begin{array}{l}77(90) \\
60(73) \\
63(76) \\
\end{array}$ & $\begin{array}{l}\text { N/A } \\
\text { N/A } \\
\text { N/A }\end{array}$ \\
\hline $\begin{array}{l}63 W-043 \\
63 W-120 \\
63 W-117 \\
63 W-128 \\
63 W-129 \\
63 W-130 \\
63 W-131 \\
63 W-138\end{array}$ & $\begin{array}{l}0.8 \mathrm{~T}(20) \\
0.5 \mathrm{~T}(20) \\
0.5 \mathrm{~T}(0) \\
0.5 \mathrm{~T}(0) \\
0.5 \mathrm{~T}(0) \\
0.5 \mathrm{~T}(0) \\
0.5 \mathrm{~T}(0) \\
0.5 \mathrm{~T}(0)\end{array}$ & $\begin{array}{l}297(267 / 328) \\
293(328 / 259) \\
282(285 / 278) \\
293(328 / 259) \\
299(320 / 278) \\
299(320 / 278) \\
299(320 / 278) \\
298(298 / 299)\end{array}$ & $\begin{array}{c}14.1(2.7 / 11.4) \\
12.6(10.9 / 1.7) \\
6.2(5.1 / 1.1) \\
12.0(10.4 / 1.6) \\
8.9(5.4 / 3.5) \\
8.4(5.2 / 3.2) \\
7.7(4.7 / 3.0) \\
8.5(6.0 / 2.5)\end{array}$ & $\begin{array}{l}171 \\
171 \\
-46 \\
-46 \\
-46 \\
-46 \\
-46 \\
-46\end{array}$ & $\begin{array}{c}136(133) \\
105(101) \\
\text { N/A } \\
\text { N/A } \\
\text { N/A } \\
\text { N/A } \\
\text { N/A } \\
\text { N/A }\end{array}$ & $\begin{array}{c}91(100) \\
83(100) \\
\text { N/A } \\
\text { N/A } \\
\text { N/A } \\
\text { N/A } \\
\text { N/A } \\
\text { N/A }\end{array}$ & $\begin{array}{c}\text { N/A } \\
\text { N/A } \\
138(119) \\
132(114) \\
55(49) \\
116(101) \\
137(118) \\
61(54)\end{array}$ \\
\hline $\begin{array}{l}64 \mathrm{~W}-040 \\
64 \mathrm{~W}-107 \\
64 \mathrm{~W}-148 \\
64 \mathrm{~W}-136 \\
64 \mathrm{~W}-138 \\
64 \mathrm{~W}-139 \\
64 \mathrm{~W}-141 \\
64 \mathrm{~W}-142 \\
64 \mathrm{~W}-143 \\
64 \mathrm{~W}-144\end{array}$ & $\begin{array}{c}0.8 \mathrm{~T}(20) \\
0.5 \mathrm{~T}(20) \\
0.5 \mathrm{~T}(20) \\
0.5 \mathrm{~T}(0) \\
0.5 \mathrm{~T}(0) \\
0.5 \mathrm{~T}(0) \\
0.5 \mathrm{~T}(0) \\
0.5 \mathrm{~T}(0) \\
0.5 \mathrm{~T}(0) \\
0.5 \mathrm{~T}(0)\end{array}$ & $\begin{array}{l}284(298 / 271) \\
286(298 / 279) \\
281(277 / 285) \\
283(279 / 288) \\
283(279 / 288) \\
283(279 / 288) \\
284(292 / 277) \\
284(292 / 277) \\
284(292 / 277) \\
282(290 / 275)\end{array}$ & $\begin{array}{l}7.7(5.2 / 2.5) \\
5.7(3.1 / 2.6) \\
5.6(0.8 / 4.8) \\
4.5(3.5 / 1.0) \\
4.8(3.7 / 1.1) \\
4.1(3.2 / 0.9) \\
5.4(4.5 / 0.9) \\
5.0(4.2 / 0.8) \\
4.4(3.7 / 0.7) \\
4.7(0.9 / 3.8)\end{array}$ & $\begin{array}{l}177 \\
177 \\
177 \\
-50 \\
-15 \\
-40 \\
-40 \\
-40 \\
-40 \\
-40\end{array}$ & $\begin{array}{c}203(201) \\
113(109) \\
129(126) \\
\text { N/A } \\
\text { N/A } \\
\text { N/A } \\
\text { N/A } \\
\text { N/A } \\
\text { N/A } \\
\text { N/A }\end{array}$ & $\begin{array}{c}124(139) \\
67(79) \\
68(84) \\
\text { N/A } \\
\text { N/A } \\
\text { N/A } \\
\text { N/A } \\
\text { N/A } \\
\text { N/A } \\
\text { N/A }\end{array}$ & $\begin{array}{c}\text { N/A } \\
\text { N/A } \\
\text { N/A } \\
47(43) \\
212(181) \\
97(85) \\
91(80) \\
76(67) \\
88(77) \\
44(40)\end{array}$ \\
\hline $\begin{array}{l}65 W-101 \\
65 W-137 \\
65 W-105 \\
65 W-133 \\
65 W-140 \\
65 W-142 \\
65 W-157 \\
65 W-160\end{array}$ & $\begin{array}{l}0.5 \mathrm{~T}(20) \\
0.5 \mathrm{~T}(20) \\
0.5 \mathrm{~T}(0) \\
0.5 \mathrm{~T}(0) \\
0.5 \mathrm{~T}(0) \\
0.5 \mathrm{~T}(0) \\
0.5 \mathrm{~T}(0) \\
0.5 \mathrm{~T}(0)\end{array}$ & $\begin{array}{l}286(289 / 283) \\
279(253 / 304) \\
287(286 / 287) \\
282(269 / 296) \\
289(320 / 259) \\
289(319 / 258) \\
278(265 / 292) \\
284(293 / 276)\end{array}$ & $\begin{array}{l}6.5(3.5 / 3.0) \\
5.6(0.8 / 4.8) \\
5.4(2.9 / 2.5) \\
4.8(2.0 / 2.8) \\
5.6(4.8 / 0.8) \\
4.7(4.0 / 0.7) \\
5.1(0.7 / 4.4) \\
4.5(3.8 / 0.7)\end{array}$ & $\begin{array}{l}200 \\
200 \\
-60 \\
-50 \\
-50 \\
-50 \\
-50 \\
-50\end{array}$ & $\begin{array}{c}128(123) \\
107(105) \\
\text { N/A } \\
\text { N/A } \\
\text { N/A } \\
\text { N/A } \\
\text { N/A } \\
\text { N/A }\end{array}$ & $\begin{array}{l}64(80) \\
70(84) \\
\text { N/A } \\
\text { N/A } \\
\text { N/A } \\
\text { N/A } \\
\text { N/A } \\
\text { N/A }\end{array}$ & $\begin{array}{c}\text { N/A } \\
\text { N/A } \\
54(49) \\
72(64) \\
100(87) \\
83(73) \\
100(87) \\
113(98)\end{array}$ \\
\hline $\begin{array}{l}66 \mathrm{~W}-117 \\
66 \mathrm{~W}-120\end{array}$ & $\begin{array}{l}0.5 \mathrm{~T}(20) \\
0.5 \mathrm{~T}(20)\end{array}$ & $\begin{array}{l}288(294 / 283) \\
279(287 / 271)\end{array}$ & $\begin{array}{l}7.6(4.1 / 3.5) \\
8.0(6.3 / 1.7)\end{array}$ & $\begin{array}{l}200 \\
200\end{array}$ & $\begin{array}{l}89(87) \\
106(98)\end{array}$ & $\begin{array}{l}16(20) \\
43(53)\end{array}$ & $\begin{array}{l}\text { N/A } \\
\text { N/A }\end{array}$ \\
\hline $\begin{array}{l}67 W-140 \\
67 W-141\end{array}$ & $\begin{array}{l}0.5 \mathrm{~T}(20) \\
0.5 \mathrm{~T}(20)\end{array}$ & $\begin{array}{l}278(269 / 286) \\
278(266 / 289)\end{array}$ & $\begin{array}{l}3.8(2.8 / 1.0) \\
7.6(0.9 / 6.7)\end{array}$ & $\begin{array}{l}200 \\
200\end{array}$ & $\begin{array}{l}130(127) \\
117(112)\end{array}$ & $\begin{array}{l}67(83) \\
62(76)\end{array}$ & $\begin{array}{l}\text { N/A } \\
\text { N/A }\end{array}$ \\
\hline \multicolumn{8}{|c|}{$\begin{array}{l}\text { "Number in parentheses indicates the percent of side grooves. } \\
\text { "First entry is the average value, while numbers in parentheses indicate irradiation temperature in } \\
\text { forward and reverse position, respectively. } \\
\text { "First entry in the total neutron fluence }(>1 \mathrm{MeV}) \text {, while number in parentheses indicate neutron } \\
\text { fluence accumulated in forward and reverse position, respectively. } \\
\text { d.First entry is the value determined according to ASTM E-1152-87, while number in parentheses } \\
\text { is the value determined from the modified version of the J-integral. } \\
\text { "Number in parentheses indicates the value of } \mathrm{K}_{\mathrm{Ic}} \text { adjusted to } 1 \mathrm{~T} \text { size. }\end{array}$} \\
\hline
\end{tabular}




$$
\mathrm{K}_{\mathrm{Jc}(\mathrm{IT})}=20+\left(\mathrm{K}_{\mathrm{Jc}(\mathrm{xT})}-20\right)\left(\frac{\mathrm{B}_{\mathrm{xT}}}{\mathrm{B}_{1 \mathrm{~T}}}\right)^{1 / 4} \text {, }
$$

where $\mathrm{B}_{(\mathrm{x})}$ and $\mathrm{B}_{(1 \mathrm{n})}$ are the test specimen and $1 \mathrm{~T}$ compact specimen thicknesses, respectively.

The scatter of fracture toughness is described by applying the statistical distribution developed by Weibull. The procedure also employs the maximum likelihood concept [10] regarded as the most accurate method of obtaining median value of fracture toughness $\left[\mathrm{K}_{\mathrm{Jc}(\mathrm{med})}\right]$ at a given test temperature:

$$
\mathrm{K}_{\mathrm{Jc}(\text { med })}=\left[\frac{\sum_{\mathrm{i}=1}^{\mathrm{N}}\left(\mathrm{K}_{\mathrm{Jc}(\mathrm{i})}-20\right)^{4}}{\mathrm{~N}-1+\ln 2} \ln 2\right]^{1 / 4}+20
$$

where $\mathrm{N}$ is the number of fracture toughness tests at the test temperature. Finally, the master curve approach for IT size specimens is applied to the median $\mathrm{K}_{\mathrm{Jc}}$ to define the temperature dependence of fracture toughness in the transition region as follows:

$$
\mathrm{K}_{\mathrm{Jc} \text { (med) }}=30+70 \exp \left[0.019\left(\mathrm{~T}-\mathrm{T}_{\mathrm{o}}\right)\right] \text {, }
$$

where $T_{0}$ is the reference temperature at $K_{\mathrm{Jc}(\mathrm{med})}=100 \mathrm{MPa} \sqrt{\mathrm{m}}$. Thus, the $T_{0}$ can be used to measure the radiation-induced shift of the transition fracture toughness and the recovery due to annealing.

In this study, attempts were made to test six specimens at the given test temperature to perform statistical analysis by Eqs. (1) through (3). In those cases where only one $\mathrm{K}_{\mathrm{Jc}}$ was obtained, the datum was not used in positioning of the master curve. The $T_{0}$ values obtained from PCVN data sets at two temperatures tended to be the same and were averaged.

Table 3 summarizes the $T_{0}$ values of welds studied in the unirradiated $\left[T_{0}(U)\right]$, irradiated $\left[\mathrm{T}_{0}(\mathrm{I})\right]$, and irradiated/annealed $\left[\mathrm{T}_{0}(\mathrm{IA})\right]$ conditions. The $\mathrm{T}_{0}$ values in irradiated condition were estimated by-the following expression:

$$
T_{0}(\mathrm{I})=\mathrm{T}_{0}(\mathrm{U})+\Delta \mathrm{RT} \mathrm{T}_{\mathrm{NDT}},
$$


where $\Delta R T_{N D T}$ is the radiation-induced shift in reference temperature (assumed equal to $\Delta \mathrm{T}_{0}$ for this study) calculated according to Regulatory Guide 1.99 (RG 1.99) [11]. According to Refs. [4,5], the RG 1.99 predictions of the radiation-induced shifts were comparable to Charpy 41-J transition temperature shifts observed for these welds following adjustment to an irradiation temperature of $288^{\circ} \mathrm{C}$. Thus, to eliminate the need for fluence adjustments in this study, it was assumed that RG 1.99 could provide reasonable estimates of radiation-induced shifts of fracture toughness. In this study, the $\Delta \mathrm{RT}_{\mathrm{NDT}}$ predictions by $\mathrm{RG} 1.99$ were made based on the average copper and nickel content (see Table 1) and the average value of neutron fluence for specimens tested in the irradiated/annealed condition.

TABLE 3--Fracture toughness transition temperatures, $T_{0}$, in the unirradiated (U), irradiated (I), and irradiated and annealed (IA) conditions

\begin{tabular}{||c|c|c|c|c|c|c||}
\hline Weld & $\begin{array}{c}\text { Neutron fluence } \\
\text { (avg. } \pm \mathrm{SD}) \\
\times 10^{18} \text { neutrons } / \mathrm{cm}^{2}\end{array}$ & $\begin{array}{c}\mathrm{T}_{\mathrm{o}} \\
(\mathrm{U}) \\
\left({ }^{\circ} \mathrm{C}\right)\end{array}$ & $\begin{array}{c}\Delta \mathrm{RT}_{\mathrm{NDT}} \\
(\mathrm{RG} 1.99) \\
\left({ }^{\circ} \mathrm{C}\right)\end{array}$ & $\begin{array}{c}\mathrm{T}_{\mathrm{o}} \\
(\mathrm{I}) \\
\left({ }^{\circ} \mathrm{C}\right)\end{array}$ & $\begin{array}{c}\mathrm{T}_{\mathrm{o}} \\
(\mathrm{IA}) \\
\left({ }^{\circ} \mathrm{C}\right)\end{array}$ & $\begin{array}{c}\mathrm{T}_{\mathrm{o}}(\mathrm{IA})-\mathrm{T}_{0}(\mathrm{U}) \\
\left({ }^{\circ} \mathrm{C}\right)\end{array}$ \\
\hline $63 \mathrm{~W}$ & $8.6 \pm 1.9$ & -90 & 110 & 20 & -44 & 46 \\
$64 \mathrm{~W}$ & $4.7 \pm 0.4$ & -59 & 98 & 39 & -12 & 47 \\
$65 \mathrm{~W}$ & $5.0 \pm 0.4$ & -80 & 74 & -6 & -33 & 47 \\
\hline \hline
\end{tabular}

Figures 1,2 , and 3 show the $K_{\mathrm{Jc}}$ values adjusted to $1 \mathrm{~T}$ size and transition master curves obtained for the welds studied in the unirradiated and annealed conditions and estimated by RG 1.99 for the irradiated condition. Each weld exhibits a broad spread of fracture toughness data in both the unirradiated and irradiated and annealed conditions. Significant scatter of the transition fracture toughness data was also reported for two other Linde 80 welds from the unirradiated Midland pressure vessel [12]. Together, these data illustrate the necessity of using a statistically based analysis procedure to characterize the fracture toughness in the transition region. The procedure used in the present work proves to be the unique tool in performance of such analysis.

Residual transition temperature shift, or difference between $T_{0}(I A)$ and $T_{0}(U)$, is used to describe the recovery of fracture toughness due to thermal annealing. In the case of welds $63 \mathrm{~W}, 64 \mathrm{~W}$, and $65 \mathrm{~W}$, the values of residual shift were 46,47 , and $47^{\circ} \mathrm{C}$, respectively. Such residual shifts indicate only partial recovery of fracture toughness in the transition temperature regime. It is interesting to note that the residual transition temperature shifts are the same despite the fact that the copper content is different for the welds studied; namely, the average copper contents are $0.30,0.35$, and $0.22 \%$ in welds $63 \mathrm{~W}, 64 \mathrm{~W}$, and $65 \mathrm{~W}$, respectively. These data will be used to evaluate the fracture toughness behavior after reirradiation, because the rate of reembrittlement is the proper attribute to evaluate the advantage of thermal annealing. 


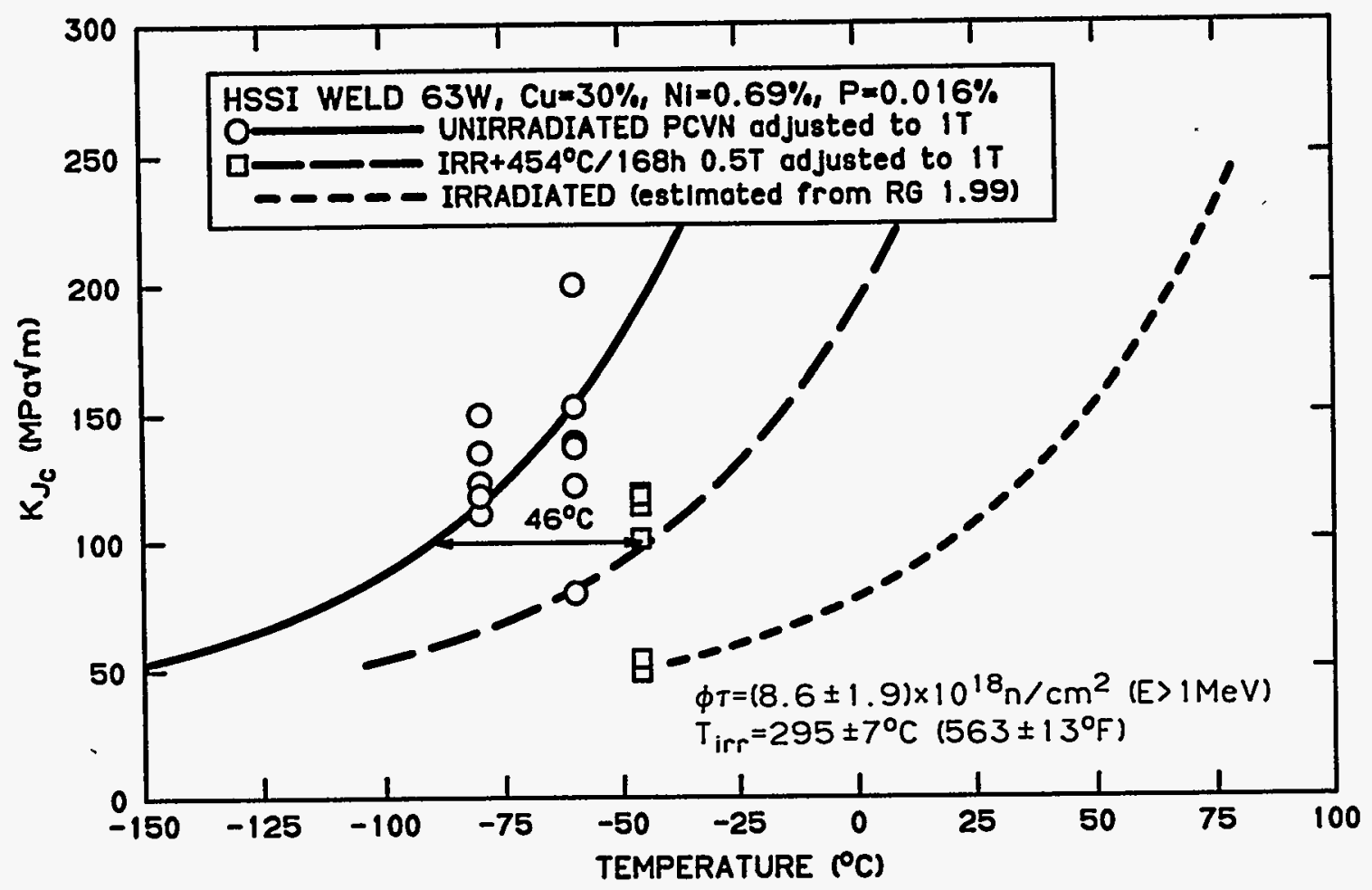

FIG. 1--Fracture toughness data and master curves of weld $63 \mathrm{~W}$ in the unirradiated, irradiated, and irradiated and annealed conditions.

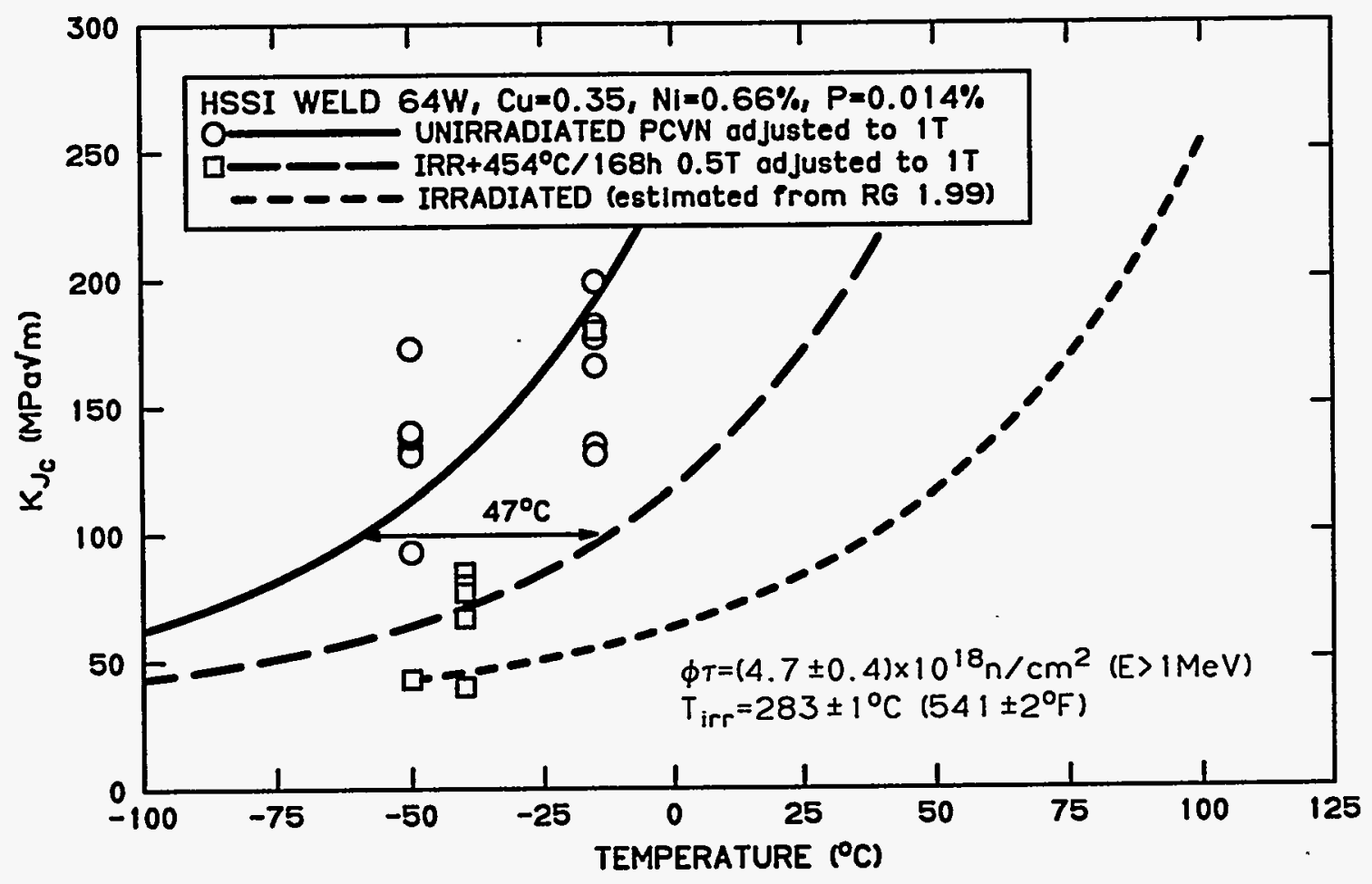

FIG. 2--Fracture toughness data and master curves of weld $64 \mathrm{~W}$ in the unirradiated, irradiated, and irradiated and annealed conditions. 


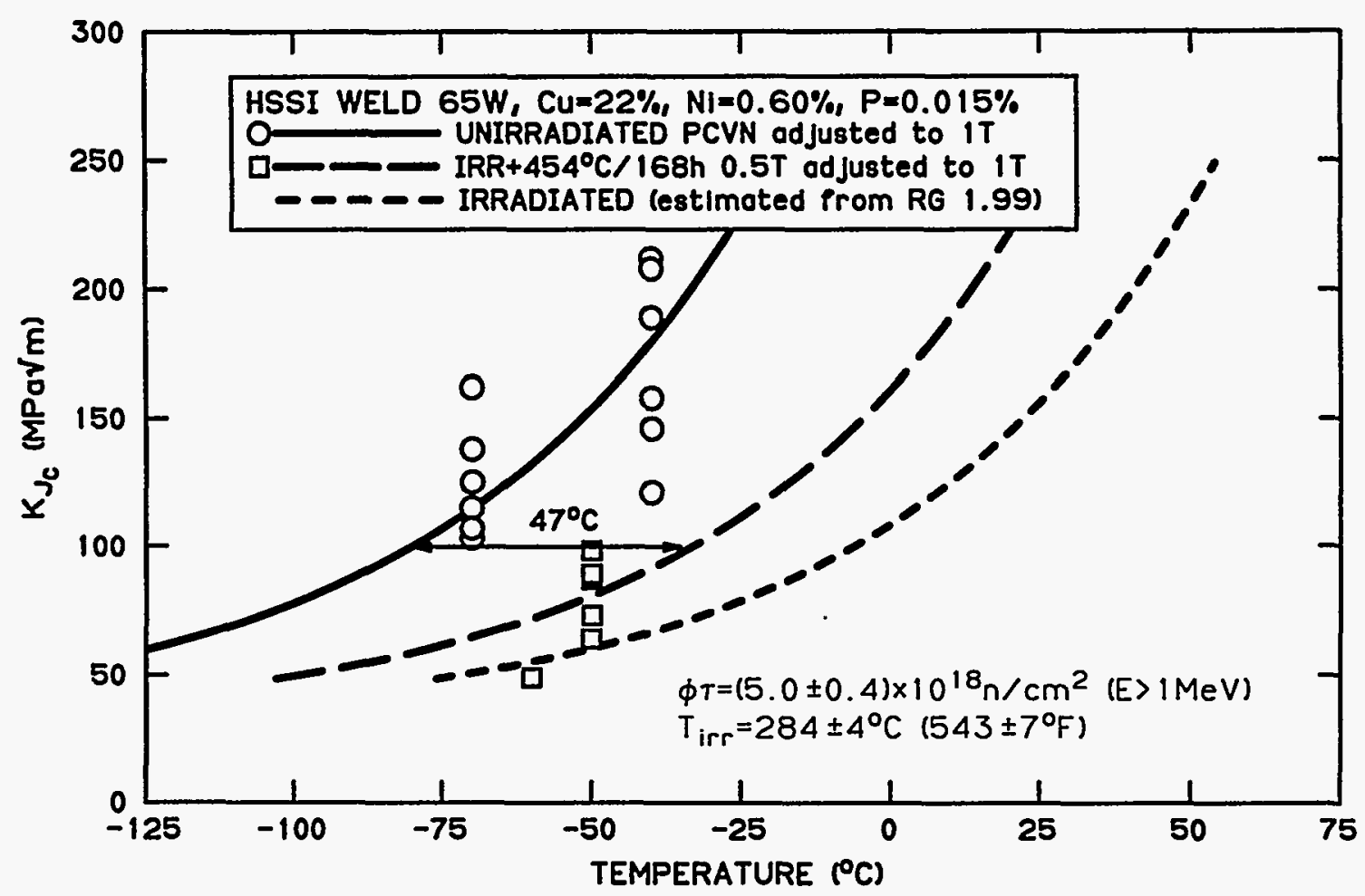

FIG. 3--Fracture toughness data and master curves of weld $65 \mathrm{~W}$ in the unirradiated, irradiated, and irradiated and annealed conditions.

\section{Tearing Resistance Characterization}

The values of the J-integral were determined using both the procedure specified in the ASTM Standard Test Method for Determining J-R Curves (E 1152-87) and a modified version of the J-integral as proposed by Ernst [13]. Modified J is used here because this version of the J-integral was chosen and reported in the previous study for the unirradiated and irradiated conditions [2]. The values of tearing modulus were determined as:

$$
\mathrm{T}_{\mathrm{avg}}=\frac{\mathrm{E}}{\sigma_{\mathrm{f}}^{2}} \frac{\mathrm{dJ}}{\mathrm{da}},
$$

where $E$ is the modulus of elasticity; $\sigma_{f}$ is the flow stress (the average of the yield and ultimate strength); and $\mathrm{dJ} / \mathrm{da}$ is the average slope of the J-R curve between the exclusion lines. The test temperatures of annealed specimens were also chosen to provide direct comparisons with the previous results in the unirradiated and irradiated conditions.

From analysis of data in Table 2, it can be seen that calculation of the J-integral by the modified version results in slightly lower values of $\mathrm{J}_{\mathrm{Ic}}$ compared to those calculated according to E 1152-87. The differences are less than $5 \%$. Primarily, use of modified 
$\mathrm{J}$-integral manifests in an increase of the J-R curve slope and, consequently, the tearing modulus.

Figure 4 presents J-R curves of welds studied after annealing at $454^{\circ} \mathrm{C}$ for $168 \mathrm{~h}$. $\mathrm{J}-\mathrm{R}$ curves of these welds in the unirradiated and irradiated conditions were digitized from the previous study [2] and they are also plotted in Fig. 4 for comparison. Table 2 provides the individual specimen results while Table 4 lists the averaged values of modified $\mathrm{J}_{\mathrm{Ic}}$ and $\mathrm{T}_{\text {avg }}$ of welds studied in the unirradiated, irradiated, and irradiated/annealed conditions. The data show that in all cases annealing at $454^{\circ} \mathrm{C}$ produces a very positive effect on recovery of J-R curves of irradiated high-copper, low upper-shelf welds. The $\mathrm{J}_{\mathrm{Ic}}$ data tend to indicate some "over recovery" after annealing, when the property of irradiated and annealed material becomes even better than the unirradiated material. The tearing modulus recovery also appears to be complete; the deviations from unirradiated values are varied from one weld to another but all are within the interval of \pm 9 .

TABLE 4--Modified $\mathrm{J}_{\mathrm{Ic}}$ and $\mathrm{T}_{\text {avg }}$ of welds $61 \mathrm{~W}$ through $67 \mathrm{~W}$ in the unirradiated $(\mathrm{U})$, irradiated (I) and irradiated and annealed (IA) conditions

\begin{tabular}{|c|c|c|c|c|c|c|c|}
\hline \multirow{2}{*}{ Weld } & \multirow{2}{*}{$\begin{array}{c}\text { Temperature } \\
\left({ }^{\circ} \mathrm{C} /{ }^{\circ} \mathrm{F}\right)\end{array}$} & \multicolumn{3}{|c|}{$\begin{array}{c}\mathrm{J}_{\mathrm{Il}} \\
\left(\mathrm{kJ} / \mathrm{m}^{2}\right)\end{array}$} & \multicolumn{3}{|c|}{$T_{\text {avg }}$} \\
\hline & & $\mathrm{U}$ & I & IA & $\mathbf{U}$ & I & IA \\
\hline $61 \mathrm{~W}$ & $121 / 250$ & 129 & 88 & 137 & 80 & 37 & 80 \\
\hline $63 \mathrm{~W}$ & $171 / 340$ & 121 & 83 & 117 & 89 & 34 & 100 \\
\hline $64 \mathrm{~W}$ & $177 / 350$ & 126 & 104 & 145 & 99 & 36 & 101 \\
\hline $65 \mathrm{~W}$ & $200 / 392$ & 107 & 91 & 114 & 89 & 50 & 82 \\
\hline $66 \mathrm{~W}$ & $200 / 392$ & 84 & 68 & 93 & 46 & 25 & 37 \\
\hline $67 \mathrm{~W}$ & $200 / 392$ & 104 & 75 & 120 & 89 & 43 & 80 \\
\hline
\end{tabular}

\section{SUMMARY}

Fracture toughness characterization of irradiated high-copper, low upper-shelf welds $61 \mathrm{~W}, 63 \mathrm{~W}, 64 \mathrm{~W}, 65 \mathrm{~W}, 66 \mathrm{~W}$, and $67 \mathrm{~W}$ after annealing at $454^{\circ} \mathrm{C}$ for $168 \mathrm{~h}$ was performed. Recovery of welds $63 \mathrm{~W}, 64 \mathrm{~W}$, and $65 \mathrm{~W}$ was studied in the transition region and on the ductile shelf. Welds $61 \mathrm{~W}, 66 \mathrm{~W}$, and $67 \mathrm{~W}$ were characterized on the ductile shelf only. The fracture toughness properties of the welds studied show the following responses to annealing at $454^{\circ} \mathrm{C}$ for $168 \mathrm{~h}$ : (1) partial recovery of the fracture toughness in the transition region $\left(\mathrm{K}_{\mathrm{Jc}}\right)$; (2) complete recovery of the tearing modulus; and (3) complete or even over-recovery of the $\mathrm{J}_{\mathrm{Ic}}$.

The data obtained for the fracture toughness properties of irradiated and annealed high-copper, low upper-shelf welds will be used to study the effects of reirradiation on the degradation of fracture toughness properties of the same welds. 

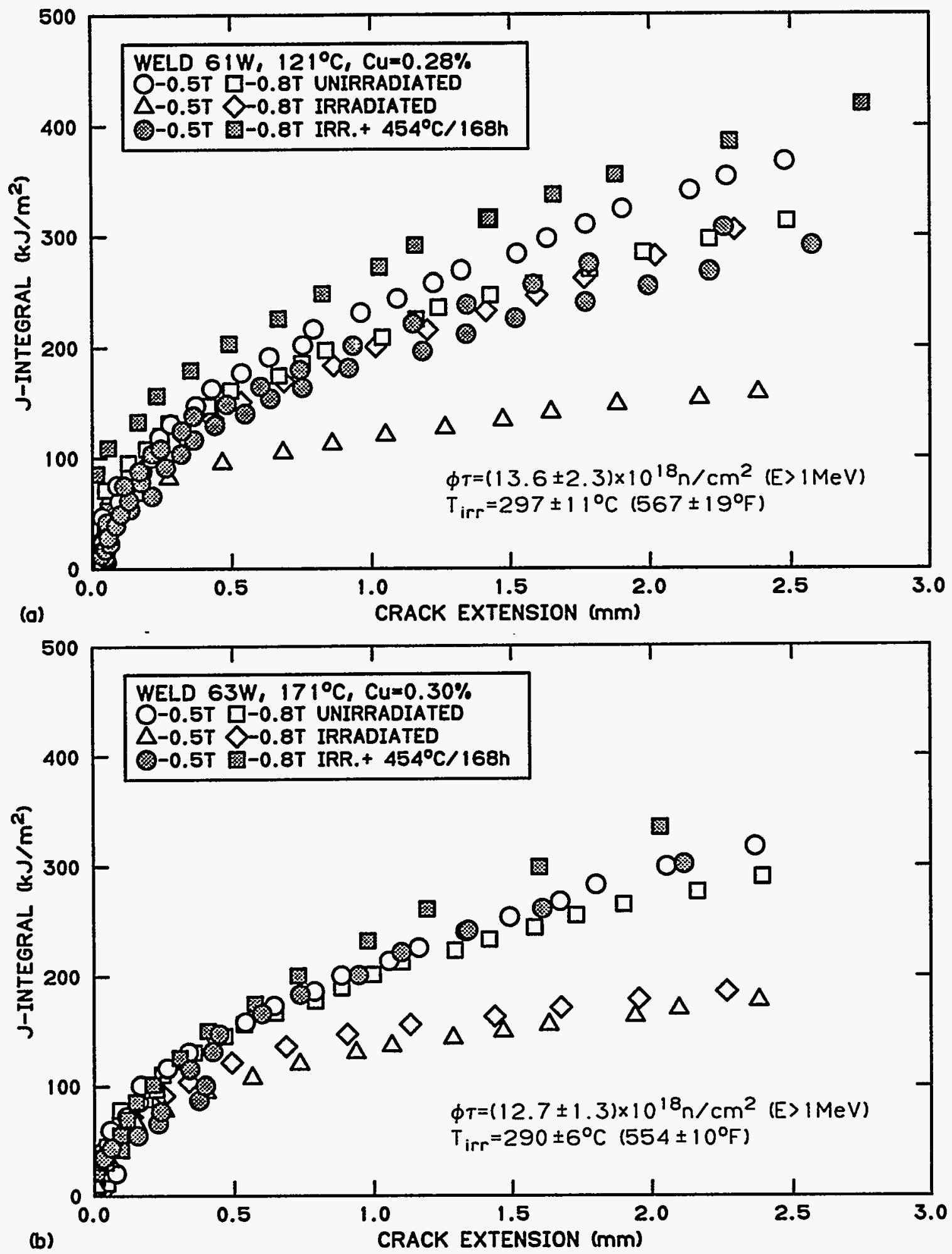

FIG. 4--J-R curves of welds (a) 61W, (b) 63W, (c) 64W, (d) $65 \mathrm{~W}$, (e) $66 \mathrm{~W}$, and (f) $67 \mathrm{~W}$ in the unirradiated, irradiated, and irradiated and annealed conditions. The unirradiated and irradiated data were digitized from A. L. Hiser, F. J. Loss, and B. H. Menke, Materials Engineering Associates, $J-R$ Curve Characterization of Irradiated Low Upper Shelf Welds, USNRC Report NUREG/CR-3506 (MEA-2028), April 1984. 

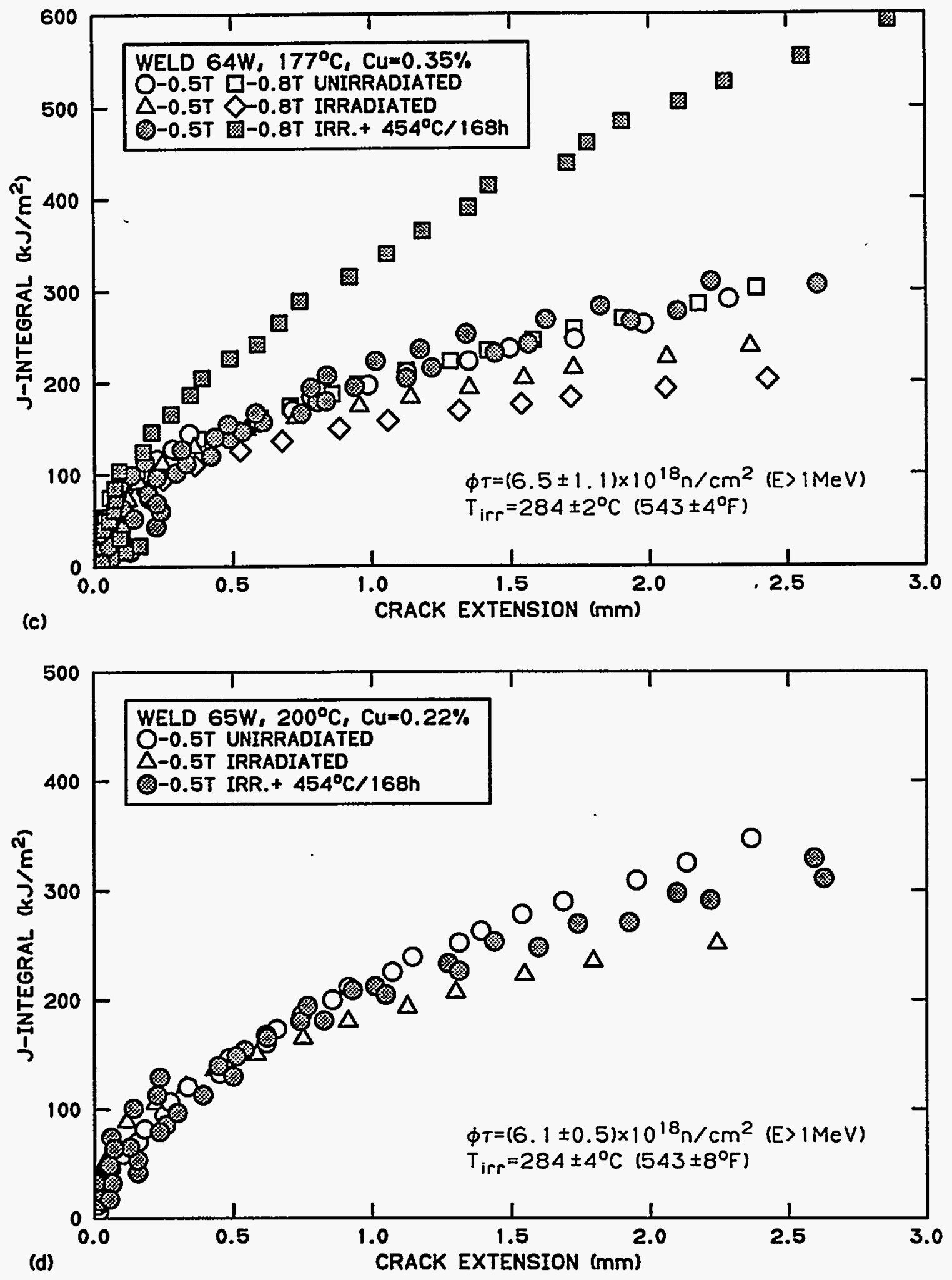

FIG. 4--(Continued) 

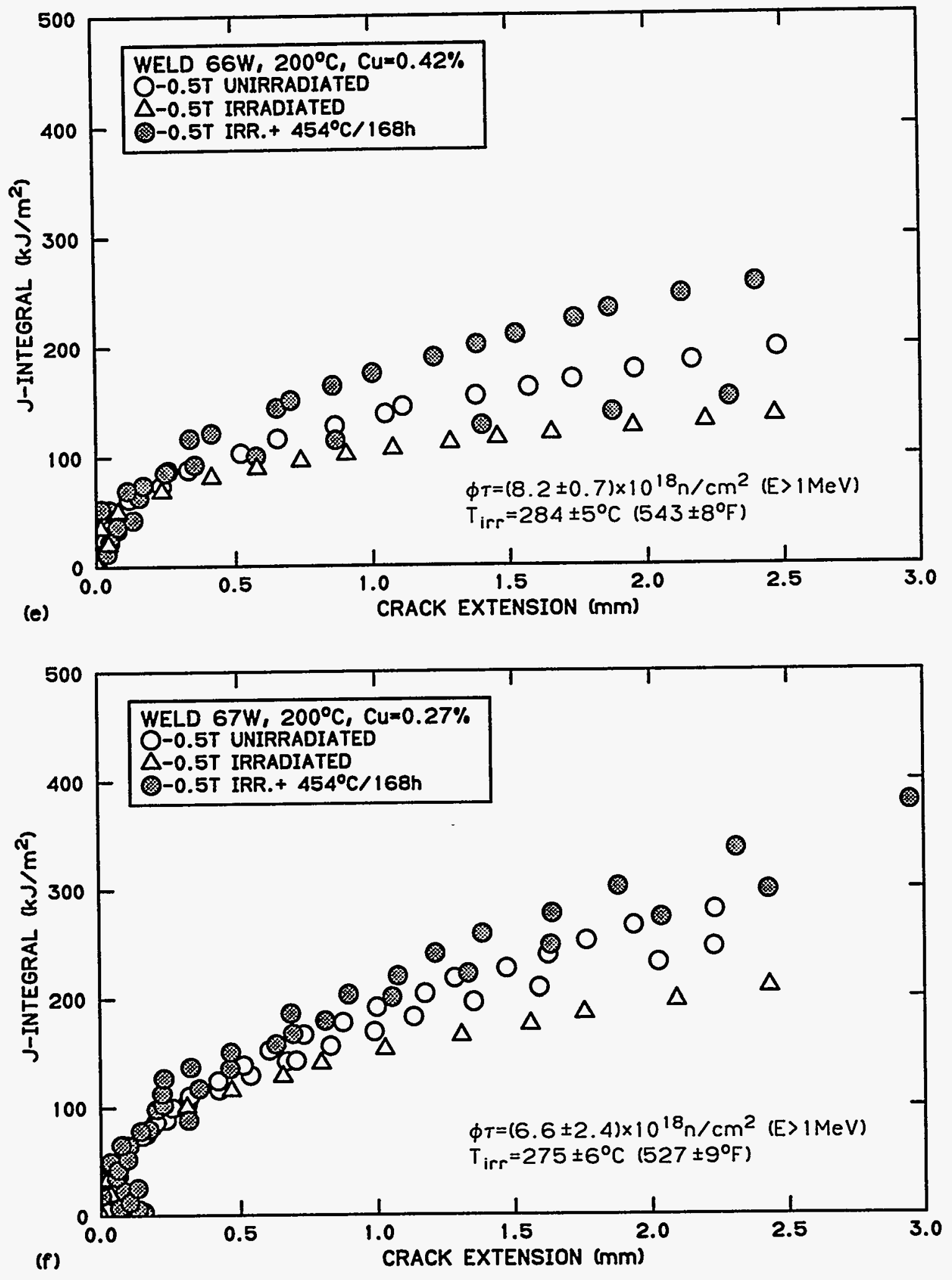

FIG. 4--(Continued) 


\section{ACKNOWLEDGMENTS}

The authors acknowledge the programmatic support of the Heavy-Section Steel Irradiation Program at ORNL by the Office of Nuclear Regulatory Research, U.S. Nuclear Regulatory Commission, under Interagency Agreement DOE 1886-8109-8L with the U.S. Department of Energy under contract DE-AC05-840R21400 with Lockheed Martin Energy Systems. The fracture toughness tests were conducted by Ronald L. Swain. Julia L. Bishop prepared the final manuscript. Dr. Ya. I. Shtrombakh, Kurchatov Institute, Moscow, is acknowledged for assistance with reconstitution of Charpy specimens. This research was supported in part by an appointment to the ORNL Postdoctoral Research Program administered by the Oak Ridge Institute for Science and Education.

\section{REFERENCES}

[1] Title 10, Code of Federal Regulations, Parts 0 to 199, U.S. Government Printing Office, January 1987.

[2] A. L. Hiser, F. J. Loss, and B. H. Menke, Materials Engineering Associates, $J-R$ Curve Characterization of Irradiated Low Upper Shelf Welds, USNRC Report NUREG/CR-3506 (MEA-2028), April 1984.

[3] A. L. Hiser, F. J. Loss, and B. H. Menke, "Fracture Toughness Characterization of Irradiated Low Upper-Shelf Welds," pp. 1131-1149 in Effects of Radiation on Materials: Twelfih International Symposium, ASTM STP 870, F. A. Garner and J. S. Perrin, Eds., American Society for Testing and Materials, Philadelphia, 1985.

[4] R. K. Nanstad and R. G. Berggren, Martin Marietta Energy Systems, Inc. Oak Ridge Natl. Lab., Irradiation Effects on Charpy and Tensile Properties of Low Upper-Shelf Welds, HSSI Series 2 and 3, USNRC Report NUREG/CR-5696 (ORNL/TM-11804), August 1991.

[5] R. K. Nanstad and R. G. Berggren, "Effects of Irradiation Temperature on Charpy Impact and Tensile Properties of High-Copper, Low Upper-Shelf, Submerged-Arc Welds," pp. 239-267 in Effects of Radiation on Materials: 16th International Symposium, ASTM STP 1175, A. S. Kumar, D. S. Gelles, R. K. Nanstad, and E. A. Little, Eds., American Society for Testing and Materials, Philadelphia, 1993.

[6] R. K. Nanstad, W. R. Corwin, D. J. Alexander, F. M. Haggag, S. K. Iskander, D. E. McCabe, and R. E. Stoller, "Heavy-Section Steel Irradiation Program on Irradiation Effects in Light-Water Reactor Pressure Vessel Materials, " pp. 297-310 in Fatigue and Crack Growth: Environmental Effects, Modeling Studies, and Design Considerations, PVP-Vol. 306, S. Yukawa, Ed., American Society of Mechanical Engineers, New York, 1995.

[7] F. W. Stallman and F. B. K. Kam, Union Carbide Nucl. Div., Oak Ridge Natl. Lab., Neutron Spectral Characterization of the Second Nuclear Regulatory Commission Heavy Section Steel Technology 4T-CT Irradiation Experiment, USNRC Report NUREG/CR-0505 (ORNL/TM-285), December 1978. 
[8] J. D. Landes, "A Calculation from Front Face Displacement Measurement on a Compact Specimen," Int. J. Fracture, 16, 93-100 (1980).

[9] K. Wallin, "Scatter in $\mathrm{K}_{\mathrm{lc}}$-Results," Eng. Fracture Mech., 19(6) 1085-1093 (1984).

[10] K. Wallin, "Validity of Small Specimens Fracture Toughness Estimates Neglecting Constraint Corrections," in Constraint Effects in Fracture: Theory and Applications, ASTM STP 1244, M. Kirk and A. Bakker, Eds., American Society for Testing and Materials, Philadelphia, 1995.

[11] U.S. Nuclear Regulatory Commission, Regulatory Guide 1.99, Revision 2, "Radiation Embrittlement of Reactor Vessel Materials," May 1988.

[12] D. E. McCabe, R. K. Nanstad, S. K. Iskander, and R. L. Swain, Martin Marietta Energy Systems, Inc., Oak Ridge Natl. Lab., Unirradiated Material Properties of Midland Weld WF-70, USNRC Report NUREG/CR-6249 (ORNL/TM-12777), 1994.

[13] H. A. Ernst, "Materials Resistance and Instability Beyond J-Controlled Crack Growth," pp. 191-213 in Elastic-Plastic Fracture, ASTM STP 803, Vol. 1, C. F. Shih and J. P. Gudas, Eds., American Society for Testing and Materials, Philadelphia, 1983. 